Al Qalam: Jurnal Ilmiah Keagamaan dan Kemasyarakatan

https://jurnal.stiq-amuntai.ac.id/index.php/al-qalam

P-ISSN: 1907-4174; E-ISSN: 2621-0681

DOI : 10.35931/aq.v16i1. 843

\title{
PERBANDINGAN MOTIVASI BELAJAR BAHASA INGGRIS ANTARA SISWA KELAS X-IPA DAN KELAS X-IPS
}

\author{
Yulianti Hidayah $^{1}$, Fathul Zannah $^{2}$, dan Nana Citrawati Lestari ${ }^{3}$ \\ ${ }^{1}$ Program Studi Pendidikan Biologi, STKIP PGRI Banjarmasin \\ yuliantihidayah79@ stkipbjm.ac.id \\ ${ }^{2}$ Program Studi Pendidikan Bahasa Inggris, STKIP PGRI Banjarmasin \\ zannahdonk@stkipbjm.ac.id \\ ${ }^{3}$ Program Studi Pendidikan Guru Sekolah Dasar, STKIP PGRI Banjarmasin \\ nanacitra@stkipbjm.ac.id
}

\begin{abstract}
ABSTRAK
Seringkali anak kelas IPA cenderung dinilai pintar dan rajin dalam belajar, namun apakah motivasi siswa jurusan IPA juga lebih tinggi dari pada siswa jurusan IPS? Berdasarkan pemikiran di atas, peneliti tertarik untuk mengetahui bagaimana perbandingan motivasi belajar bahasa Inggris antara siswa kelas X-IPA dan kelas X IPS di SMAN 5 Banjarmasin. Tujuan penelitian ini adalah untuk mengetahui perbandingan motivasi siswa belajar bahasa Inggris antara siswa kelas X-IPA dan siswa kelas X IPS di SMAN 5 Banjarmasin. Adapun perbandingan motivasi berfokus pada motivasi integratif dan motivasi instrumental. Jenis penelitian yang digunakan dalam penelitian ini adalah penelitian deskriptif. Data penelitian ini bersumber dari data primer yang dikumpulkan melalui angket/kuesioner google form. Teknik analisa data yang digunakan yaitu metode analisis deskriptif persentase dengan menghitung frekuensi dan persentase jawaban pada tiap butir angket. Berdasarkan kesimpulan diketahui bahwa motivasi belajar integratif maupun motivasi belajar instrumental siswa kelas X-IPA lebih rendah daripada siswa kelas X IPS.
\end{abstract}

Kata kunci: belajar, bahasa inggris, IPA, IPS, motivasi

\begin{abstract}
Often science (IPA) students tend to be considered smart and diligent in studying, but is the motivation of students majoring in science also higher than students majoring in social studies (IPS)? Based on the above thoughts, the researcher is interested in knowing how to compare the motivation to learn English between students in class X-IPA science and grade X-IPS social studies at SMAN 5 Banjarmasin. The purpose of this study was to determine the comparison of students' motivation to learn English between students in class $X$ IPA and class $X$ social studies at SMAN 5 Banjarmasin. The comparison of motivation focuses on integrative motivation and instrumental motivation. The type of research used in this research is descriptive research. The data of this study were sourced from primary data collected through a google form questionnaire/questionnaire. The data analysis technique used is the descriptive percentage analysis method by calculating the frequency and percentage of answers to each item in the questionnaire. Based on the conclusion, it is known that the integrative learning motivation and the instrumental learning motivation of students in class X-IPA are lower than students in class X social studies.
\end{abstract}

Keywords: learning, English, science, sosial studies, motivation

Al Qalam: Jurnal Ilmiah Keagamaan dan Kemasyarakatan Vol. 16, No. 1 Januari - Juni 2022 
Yulianti Hidayah, Fathul Zannah, Nana Citrawati Lestari : Perbandingan Motivasi Belajar Bahasa Inggris Antara Siswa Kelas X-IPA dan Kelas X-IPS

\section{PENDAHULUAN}

Sebagian besar siswa SMA telah mempelajari bahasa Inggris secara formal sejak tingkat sekolah dasar, namun masih dapat dikatakan belum memadai. Mempelajari bahasa Inggris merupakan hal penting (Warniati,2020). Bahasa inggris menjadi wadah yang menjadikan generasi kita menjadi berkualitas dan mampu bersaing dalam menghadapi tuntutan zaman yang akan datang. Bahasa inggris merupakan alat berkomunikasi secara lisan dan tertulis dalam dunia modern sekarang, kita tidak bisa memungkiri tingginya tingkat persaingan yang ada, setiap orang tidak hanya di harapkan memiliki tingkat pendidikan yang tinggi saja, akan tetapi juga di tuntut akan adanya ketrampilan khusus dimana salah satunya mempunyai anak memiliki keterampilan berbahasa Inggris dengan apapun jurusan sekolah yang mereka jalani di sekolah. Peranan bahasa Inggris juga sangat di perlukan dalam teknologi ${ }^{1}$. Pada kenyataannya, kemajuan teknologi semakin hari dan semakin tahun selalu berkembang. Tuntutan untuk pengaplikasian melalui teknologipun tidak bisa di tepis.mau tidak mau haruslah mau. Oleh karena itu,mengapa Bahasa Inggris menjadi penting untuk di pelajari di SMA dan perlu diketahui serta mengulas bagaimana motivasi siswa SMA dalam mempelajarinya.

Motivasi kuat juga menjadi salah satu alasan serta hal penting yang diperlukan dalam mempelajari bahasa Inggris. Faktor utama yang memang sangat perlu di garis bawahi adalah motivasi belajar siswa itu sendiri. Rasa aman dan nyaman akan sangat berpengaruh pada psikis atau psikolgi anak didik kita. Mereka belajar bahasa inggris karena mereka memang memiliki motivasi belajar dalam diri mereka ${ }^{2}$. Tidak ada paksaan ataupun tuntutan dari siapapun, sekalipun itu adalah orang tua mereka sendiri. Motivasi belajar ialah suatu penggerak psikis yang ada dalam dan atau luar diri siswa dalam menimbulkan kegiatan belajar, agar terjamin dalam kelancaran aktivitas belajarnya, serta mengarahkan aktivitas belajarnya kepada tujuan yang ingin dicapai ${ }^{3}$. Kemauan yang kuat yang mengggerakkan minat menjadi motivasi dalam diri. Siswa sangat membutuhkan motivasi dalam belajar, karena hasil belajar pun menjadi optimal dengan adanya motivasi belajar yang tinggi. Kualitas dari hasil belajarpun akan bisa dipastikan bisa diraih karena motivasi diri untuk belajar. Jadi motivasi akan senantiasa menentukan intensitas usaha belajar bagi para siswa. Selain itu, motivasi dapat berfungsi sebagai pendorong usaha dan pencapaian prestasi.

\footnotetext{
${ }^{1}$ Muh. Sauki Maulana Pentingnya Bahasa Inggris untuk anak usia Dini di Kelurahan Mangasa, Jurnal lepa lepa Open:Jurnal Pengabdian Masyarakat, 2020.

2 I Wayan Suryasa, An analysis of student's motivation toward English Learning Among students in PEACE, International Journal of Social Sciences and Humanities, 2017.

${ }^{3}$ Ilham Taufiqurrochman, Faktor-Faktor Yang Mempengaruhi Motivasi Belajar Bahasa Inggris. Skripsi. Surakarta: Universitas Muhammadiyah Surakarta, 2018.
}

Al Qalam: Jurnal Ilmiah Keagamaan dan Kemasyarakatan Vol. 16, No. 1 Januari - Juni 2022 
Yulianti Hidayah, Fathul Zannah, Nana Citrawati Lestari : Perbandingan Motivasi Belajar Bahasa Inggris Antara Siswa Kelas X-IPA dan Kelas X-IPS

Fenomena di masyarakat seringkali memperdebatkan mana yang lebih baik: apakah jurusan IPA atau IPS? Ini adalah pertanyaan sejuta pelajar - dimana dulu saat SMA, sekarang sebelum masuk SMA. Bahkan setelah pemilihan jurusan di sekolah mengalami pergeseran masa, perdebatan IPA dengan IPS tetap berlangsung. Tanpa disadari yang membuat diskriminasi di antara dua jurusan tersebut adalah adanya pembiaran stigma itu terus hidup di masyarakat. Padahal, anak jurusan IPA dan anak jurusan IPS sama-sama memiliki kemampuan yang setara. Mereka memiliki kemampuan di masing masing bidang. Dengan jurusan, mereka akan lebih terarah dalam mengambil keputusan untuk memilih universitas atau perguruan tinggi mana yang akan menunjang cita cita mereka. Stigma seperti ini terus saja tumbuh dan anehnya tidak menghilang, meskipun generasi sudah berganti dengan generasi yang lebih baik kualitas pendidikannya tiap tahunnya dan hal ini masih saja berpikiran seperti itu hingga saat ini. Menjadikan hal ini tersebut seperti budaya yang turun temurun. Seolah olah anak IPA adalah anak emas, sedangkan anak IPS hanyalah anak buangan. Pada kenyataannya yang menentukan diri kita berkualitas adalah diri kita sendiri. Tentunya, ini tergantung diri kita sendiri. Sebenarnya kita ingin jadi pelajar yang seperti apa, bagaimana proses belajarnya, bagaimana pelajar tersebut membangun motivasi dalam dirinya sendiri dan seterusnya. Seringkali anak IPA cenderung selalu dinilai pintar dan rajin dalam belajar, labelling terhadap anak IPA yang di anggap rajin dan lebih pintar ini tentu saja sedikit banyak akan berdampak pada keadaan psikologis anak lain, contoh anak IPS. Pelabelan anak pintar dan lebih rajin ini pasti akan berdampak pada semua aspek termasuk pada motivasi belajar ${ }^{4}$. Label tersebut menjadikan anak jatuh ke lubang yang sama yaitu anak IPA lebih pintar dan rajin. Sedangkan anak IPS? Stigma itu akan hanya selalu berkutat pada hal itu saja dan faktor penyebabnya adalah tidak jauh dari kata masyarakat yang masih terkungkung dengan kalimat interpretasi yang salah. Padahal yang menjadi pertanyaan besar adalah apakah motivasi siswa jurusan IPA juga lebih tinggi dari pada siswa jurusan IPS?

Berdasarkan pemikiran di atas, peneliti tertarik untuk mengetahui bagaimana perbandingan motivasi belajar bahasa Inggris antara siswa kelas X-IPA dan kelas X IPS di SMAN 5 Banjarmasin. Dengan mengetahui perbandingan motivasi tersebut peneliti bertujuan memberikan adanya kontribusi melalui penelitian ini untuk menjadi review segala aspek.

${ }^{4}$ Rahman SK,Abd,dkk, Labelling (Studi Komparatif Pada Siswa Jurusan IPA dan IPS di MAN BINAMU JENEPONTO), Jurnal sosialisasi: Jurnal Hasil Pemikiran, Penelitian dan Pengembangan Keilmuan Sosiologi Pendidikan, 2019

Al Qalam: Jurnal Ilmiah Keagamaan dan Kemasyarakatan Vol. 16, No. 1 Januari - Juni 2022 
Yulianti Hidayah, Fathul Zannah, Nana Citrawati Lestari : Perbandingan Motivasi Belajar Bahasa Inggris Antara Siswa Kelas X-IPA dan Kelas X-IPS

\section{METODE PENELITIAN}

Jenis penelitian yang digunakan dalam penelitian ini adalah deskriptif kuantitatif. Penelitian ini menggunakan analisis deskriptif untuk menganalisa data yang dikumpulkan melalui kuesioner. Pendekatan yang digunakan adalah pendekatan kuantitatif, yakni penelitian yang analalisisnya lebih fokus pada data-data numerikal (angka) yang diolah dengan menggunakan metode statistika (Azwar, 2011). Dengan demikian, penelitian ini akan menjelaskan keadaan dari objek yang diteliti dan kemudian menganalisis kebenarannya. Penelitian kuantitatif digunakan untuk mengetahui tingkat motivasi belajar siswa, sedangkan penelitian kualitatif digunakan untuk menjelaskan perbandingan antara motivasi belajar siswa kelas IPA dan kelas IPS berdasarkan data yang diperoleh.

Data penelitian ini bersumber dari data primer yang dikumpulkan oleh peneliti melalui upaya pengambilan data dengan alat ukur berupa kuesioner melalui media google form.

Subjek penelitian atau responden adalah siswa SMA kelas X-IPA dan X-IPS. Masingmasing kelas diambil 25 orang responden. Analisa data dilakukan dengan cara melihat frekuensi dan persentase motivasi siswa dimana persepsi mahasiswa akan dibagi menjadi 2 kategori yaitu motivasi kelas IPA dan IPS. Analisa data yang digunakan bertujuan untuk mengetahui gambaran tentang perbedaan motivasi antara siswa IPA dan IPS. Teknik analisa data yang digunakan dalam penelitian ini yaitu menggunakan metode analisis deskriptif persentase, yaitu menghitung frekuensi dan persentase jawaban pada tiap butir angket. Setiap jawaban dari pertanyaan pada angket dihitung dan diklasifikasikan berdasarkan besar presentase jawaban. Klasifikasi intepretasi jumlah jawaban responden tersebut adalah sebagai berikut:

Tabel 1. Persentase motivasi

\begin{tabular}{|c|c|}
\hline Interval (\%) & Kategori \\
\hline $81,26-100$ & Sangat Tinggi \\
\hline $62,51-81,25$ & Tinggi \\
\hline $43,76-62,50$ & Rendah \\
\hline $25,00-43,75$ & Sangat rendah \\
\hline
\end{tabular}

Perhitungan dengan menggunakan rumus deskriptif persentase ini mempunyai langkahlangkah sebagai berikut ini.

1. Mengoreksi jawaban angket dari responden

2. Menghitung frekuensi jawaban responden

3. Jumlah responden keseluruhan 50 orang

4. Masukkan kedalam rumus

\section{HASIL DAN PEMBAHASAN}

Al Qalam: Jurnal Ilmiah Keagamaan dan Kemasyarakatan Vol. 16, No. 1 Januari - Juni 2022 
Yulianti Hidayah, Fathul Zannah, Nana Citrawati Lestari : Perbandingan Motivasi Belajar Bahasa Inggris Antara Siswa Kelas X-IPA dan Kelas X-IPS

Motivasi belajar adalah seluruh daya penggerak dalam diri siswa yang mengakibatkan terjadinya proses kegiatan belajar, yang menjamin kelangsungan dari proses kegiatan belajar dan memberikan arah pada kegiatan belajar sehingga tujuan pembelajaran yang diharapkan siswa bisa tercapai ${ }^{5}$. Perbandingan motivasi belajar antara siswa kelas X-IPA dan kelas X IPS di SMAN 5 Banjarmasin berfokus pada motivasi integratif dan motivasi instrumental. Hasil penelitian disajikan pada Tabel 2 dan Tabel 3 di bawah ini.

Tabel 2. Perbandingan Persentase Jawaban Ya untuk Motivasi Integratif Antara Kelas IPA dan Kelas IPS

\begin{tabular}{|c|l|c|c|c|c|}
\hline \multirow{2}{*}{ No } & \multicolumn{1}{|c|}{ Motivasi } & \multicolumn{3}{c|}{ Persentase Jawaban Ya (\%) } \\
\cline { 3 - 6 } & \multicolumn{2}{|c|}{$\begin{array}{c}\text { IPA } \\
\text { Persentase } \\
(\%)\end{array}$} & Kategori & $\begin{array}{c}\text { Persentase } \\
(\%)\end{array}$ & Kategori \\
\hline 1 & Minat & 80 & Tinggi & 80 & Tinggi \\
\hline 2 & Perasaan senang & 80 & Tinggi & 80 & Tinggi \\
\hline 3 & $\begin{array}{l}\text { Komunikasi dengan orang } \\
\text { luar }\end{array}$ & 68 & Tinggi & 100 & $\begin{array}{c}\text { Sangat } \\
\text { Tinggi }\end{array}$ \\
\hline 4 & $\begin{array}{l}\text { Penggunaan internet (dunia } \\
\text { maya) dan media sosial }\end{array}$ & 100 & $\begin{array}{l}\text { Sangat } \\
\text { Tinggi }\end{array}$ & 100 & $\begin{array}{c}\text { Sangat } \\
\text { Tinggi }\end{array}$ \\
\hline 5 & $\begin{array}{l}\text { Status sosial (tingkat } \\
\text { pendidikan dan gengsi) }\end{array}$ & 76 & Tinggi & 100 & $\begin{array}{c}\text { Sangat } \\
\text { Tinggi }\end{array}$ \\
\hline \multicolumn{1}{|c|}{ Rerata } & 80,8 & Tinggi & 92 & $\begin{array}{c}\text { Sangat } \\
\text { Tinggi }\end{array}$ \\
\hline
\end{tabular}

Berdasarkan hasil pada Tabel 2 di atas dapat diketahui beberapa hal berikut.

1. Minat

Minat siswa antara siswa kelas IPA dan IPS terhadap bahasa Inggris sama-sama tinggi dengan angka persentase sebesar $80 \%$. Siswa yang memiliki minat terhadap sesuatu bidang studi tertentu cenderung tertarik perhatiannya dan dengan demikian timbul motivasinya untuk mempelajari bidang studi tersebut. Motivasi juga dipengaruhi oleh nilai-nilai yang di anggap penting dalam kehidupan. Nilai-nilai tersebut mengubah tingkah laku dan motivasinya ${ }^{6}$.

Minat adalah kecenderungan yang tetap untuk memperhatikan mengenang beberapa kegiatan. Kegiatan yang diamati seseorang, diperhatikan terus-menerus yang disertai dengan rasa senang. Jadi berbeda dengan perhatian. Karena perhatian sifatnya sementara (tidak dalam waktu yang lama) dan belum tentu diikuti dengan perasaan senang, sedangkan minat selalu

${ }^{5}$ Arianti,A, Peranan Guru Dalam Meningkatkan Motivasi Belajar Siswa, Didaktika:Jurnal pendidikan, 2019.

${ }^{6}$ Bastari, E. Hubungan Motivasi Belajar peserta didik pada mata pelajaran IPS kelas IV SD Negeri 1 Sukabumi indah bandar lampung, Jurnal UIN Bandarlampung, 2019.

Al Qalam: Jurnal Ilmiah Keagamaan dan Kemasyarakatan Vol. 16, No. 1 Januari - Juni 2022 
Yulianti Hidayah, Fathul Zannah, Nana Citrawati Lestari : Perbandingan Motivasi Belajar Bahasa Inggris Antara Siswa Kelas X-IPA dan Kelas X-IPS

diikuti dengan perasaan senang dan dari itu diperoleh kepuasan. Minat akan tumbuh dengan baik karena adanya psikologis yang sehat.

2. Perasaan senang

Baik siswa kelas IPA maupun kelas IPS sama-sama menyenangi pembelajaran bahasa Inggris. Hal ini terlihat dari kategori motivasi perasaan senang yang sama-sama tinggi. Menurut Lestari dan Mokhammad (2017:93-94), indikator dari minat belajar adalah 1) perasaan senang, 2) ketertarikan untuk belajar, 3) menunjukkan perhatian saat belajar, 4) keterlibatan dalam belajar.

3. Komunikasi dengan orang luar

Bahasa Inggris sebagai salah satu bahasa internasional memainkan peranan yang penting untuk berkomunikasi dengan dunia luar khususnya dalam menyerap ilmu pengetahuan dan teknologi. Salah satu aspek yang perlu dikuasai oleh siswa adalah kemampuan berbahasa Inggris yang baik, baik lisan maupun tertulis. Kemampuan bahasa Inggris yang baik harus menguasai keempat keterampilan bahasa dan kosa kata serta tata bahasa ${ }^{7}$. Siswa kelas IPS lebih banyak yang mengganggap bahwa belajar bahasa Inggris itu penting karena dapat berkomunikasi dan mengenal orang dari mancanegara. Hal ini terlihat dari kategori motivasi komunikasi dengan orang luar kelas IPA dengan kategori tinggi sedangkan kelas IPS dengan kategori sangat tinggi.

Bahasa Inggris hendaknya mendapat perhatian yang lebih serius dalam pendidikan nasional dengan tujuan semua siswa harus mendapat kesempatan belajar bahasa Inggris sebagai bahasa (kebudayaan) bukan pengetahuan yang melulu bersandar pada grammar semata. Artinya siswa sejak dini harus belajar memakai bahasa sebagai alat komunikasi. Saatnya menumbuhkan keberanian dalam diri siswa untuk berkomunikasi secara lisan. Apalagi dengan tuntuta zaman yang sekarang bahasa inggris menjadi sebuah kebutuhan. Dengan kesadaran akan pentingnya mempelajari bahasa Inggris agar bisa berkomunikasi dengan orang luar merupakan suatu hal yang positif dan dapat memotivasi diri untuk belajar lebih giat,

4. Penggunaan internet (dunia maya) dan media sosial

Baik siswa kelas IPA maupun kelas IPS sama-sama berpendapat bahwa dengan belajar bahasa Inggris dapat membuat mereka lebih mudah berinteraksi dengan dunia maya dan media sosial. Dengan memahami kalimat berbahasa Inggris maka akan lebih mempermudah dalam pengoperasian berbagai jejaring media sosial meskipun beberapa aplikasi sudah menyertakan pilihan bahasa Indonesia. Seperti yang disebutkan oleh Yani dkk. (2018) melalui hasil

${ }^{7}$ Cahyani,EP, Hubungan antara Minat Belajar dan resiliensi matematis, E-journal.bbg.ac.id, 2018

Al Qalam: Jurnal Ilmiah Keagamaan dan Kemasyarakatan Vol. 16, No. 1 Januari - Juni 2022 
Yulianti Hidayah, Fathul Zannah, Nana Citrawati Lestari : Perbandingan Motivasi Belajar Bahasa Inggris Antara Siswa Kelas X-IPA dan Kelas X-IPS

penelitiannya bahwa peranan bahasa asing sangatlah diperlukan dalam mengusai teknologi komunikasi maupun dalam berinteraksi secara langsung.

5. Status sosial (tingkat pendidikan dan gengsi)

Pola pikir penggunaan bahasa Inggris pada masyarakat perkotaan merepresentasikan secara simbolik bahwa bahasa asing harus dikuasai dan digunakan sehari-hari. Penggunaan bahasa Inggris sebagai bahasa utama dianggap dapat menyimbolkan prestise, dan menjanjikan kedudukan serta taraf sosial ekonomi yang jauh lebih baik (Prayoga \& Khatimah, 2019). Siswa kelas IPS lebih banyak yang berpendapat bahwa dengan belajar bahasa Inggris dapat membuat mereka merasa berpendidikan dan bergengsi. Hal ini terlihat dari tingkat motivasi kelas IPS dengan kategori sangat tinggi sedangkan kelas IPA dengan kategori tinggi saja.

Tabel 3. Perbandingan Persentase Jawaban Ya untuk Motivasi Instrumental Antara Kelas IPA dan Kelas IPS

\begin{tabular}{|c|c|c|c|c|c|}
\hline \multirow{3}{*}{ No } & \multirow{3}{*}{ Motivasi } & \multicolumn{4}{|c|}{ Persentase Jawaban Ya (\%) } \\
\hline & & \multicolumn{2}{|c|}{ IPA } & \multicolumn{2}{|c|}{ IPS } \\
\hline & & $\begin{array}{l}\text { Persentase } \\
(\%)\end{array}$ & Kategori & $\begin{array}{l}\text { Persentase } \\
(\%)\end{array}$ & Kategori \\
\hline 1 & $\begin{array}{l}\text { Keterkaitan dengan jurusan } \\
\text { yang dipilih }\end{array}$ & 52 & Rendah & 100 & $\begin{array}{l}\text { Sangat } \\
\text { Tinggi }\end{array}$ \\
\hline 2 & $\begin{array}{l}\text { Keterkaitan dengan sumber } \\
\text { pelajaran }\end{array}$ & 40 & $\begin{array}{l}\text { Sangat } \\
\text { Rendah }\end{array}$ & 80 & Tinggi \\
\hline 3 & Penunjang studi dan karir & 68 & Tinggi & 100 & $\begin{array}{l}\text { Sangat } \\
\text { Tinggi }\end{array}$ \\
\hline 4 & $\begin{array}{l}\text { Ketekunan dalam } \\
\text { mempelajari mata pelajaran }\end{array}$ & 72 & Tinggi & 100 & $\begin{array}{l}\text { Sangat } \\
\text { Tinggi }\end{array}$ \\
\hline 5 & Perilaku terhadap pengajar & 76 & Tinggi & 100 & $\begin{array}{l}\text { Sangat } \\
\text { Tinggi }\end{array}$ \\
\hline & Rerata & 61,6 & Rendah & 96,0 & $\begin{array}{l}\text { Sangat } \\
\text { Tinggi }\end{array}$ \\
\hline
\end{tabular}

Berdasarkan hasil pada Tabel 3 di atas dapat diketahui beberapa hal berikut.

1. Keterkaitan dengan jurusan yang dipilih.

Semua siswa kelas IPS yang menjadi responden berpendapat bahwa pelajaran bahasa Inggris mempunyai hubungan yang penting dengan jurusan yang mereka pilih. Sementara untuk siswa kelas IPA hanya 52\% saja yang mempunyai pendapat serupa. Padahal kedua jurusan tersebut sama-sama memerlukan penguasaan bahasa Inggris dasar agar lebih mudah dalam melaksanakan pembelajaran karena pada kedua jurusan tersebut tetap ada pembelajaran bahasa Inggris.

2. Keterkaitan dengan sumber pelajaran

Motivasi siswa kelas IPA bisa dikatakan sebagian besar bukan karena menganggap bahwa belajar bahasa Inggris dapat membuat mereka lebih mudah memahami sumber belajar

Al Qalam: Jurnal Ilmiah Keagamaan dan Kemasyarakatan Vol. 16, No. 1 Januari - Juni 2022 
Yulianti Hidayah, Fathul Zannah, Nana Citrawati Lestari : Perbandingan Motivasi Belajar Bahasa Inggris Antara Siswa Kelas X-IPA dan Kelas X-IPS

berupa artikel, video, majalah, dan lain-lainnya yang berupa teks atau audio berbahasa Inggris. Hal ini dapat dilihat bahwa persentase siswa IPA yang melilih ya untuk pertanyaan tentang keterkaitan bahasa Inggris dengan sumber pelajaran hanya sebesar $40 \%$ sehingga dapat dikategorikan sangat rendah. Namun sebaliknya dengan siswa kelas IPA, siswa kelas IPS justru mempunyai persentase yang tinggi yaitu sebesar $80 \%$.

3. Penunjang studi dan karir

Peranan bahasa asing sangatlah diperlukan dalam menguasai teknologi komunikasi maupun dalam berinteraksi secara langsung. Dengan kemampuan bahasa asing yang baik, akan terbuka banyak kesempatan untuk memperoleh pekerjaan yang baik di Perusahaan Multinasional yang memang mensyaratkan kemampuan bahasa asing yang baik, untuk memperluas pergaulan di Dunia Internasional karena bahasa asing merupakan bahasa yang secara umum bermanfaat untuk dapat bersaing di Era Globalisasi ${ }^{8}$.

Jumlah siswa yang menjawab Ya untuk pertanyaan tentang penunjang studi dan karis berbeda antara siswa kelas IPA dengan siswa kelas IPS. Persentase jawaban Ya oleh siswa kelas IPA adalah sebesar 68\% sehingga mendapat kategori tinggi. Sedangkan untuk siswa kelas IPS persentase jawaban Ya adalah sebesar 100\% sehingga dikategorikan sangat tinggi.

4. Ketekunan dalam mempelajari mata pelajaran

Ketekunan belajar sangat penting ditanamkan siswa sejak dini. Karena ketekunan dapat meraih kesuksesan seseorang. Seseorang yang tekun tidak pernah puas dengan hasil yang diperoleh. Sehingga akan terus berusaha dengan gigih untuk bisa berhasil. Ketekunan belajar merupakan keseriusan dalam proses pembelajaran yang bertujuan untuk meraih hasil yang terbaik (Septiani, 2019).

Untuk jawaban "Ya" dari pertanyaan tentang ketekunan dalam mempelajari mata pelajaran untuk kelas IPA sebanyak $72 \%$, termasuk kategori tinggi. Lalu untuk siswa kelas IPS sebanyak $100 \%$ dan mendapat kategori sangat tinggi karena seluruh siswa kelas IPS yang menjadi responden menjawab "Ya".

5. Perilaku terhadap pengajar

Motivasi perilaku terhadap pengajar pada angket ditulis menjadi sebuah pertanyaan yang berbunyi "apakah kamu menganggap guru bahasa Inggris itu keren, gaul, dan menyenangkan dalam mengajar?". Adapun persentase jawaban ya untuk motivasi "Perilaku terhadap pengajar" untuk siswa kelas IPA adalah sebesar 76\% dengan kategori tinggi, sedangkan

8 Yani, IA,Ratnamulyani,AA kusumadinata, Pengaruh Kompetensi Berbahasa Asing Dan Pengorganisasian Dalam Menunjang Karir Di Bidang Public Relation, Jurnal Komunikatio-Unida.ac.id, 2018.

Al Qalam: Jurnal Ilmiah Keagamaan dan Kemasyarakatan Vol. 16, No. 1 Januari - Juni 2022 
Yulianti Hidayah, Fathul Zannah, Nana Citrawati Lestari : Perbandingan Motivasi Belajar Bahasa Inggris Antara Siswa Kelas X-IPA dan Kelas X-IPS

untuk siswa kelas IPS sebesar 100\% dengan kateori sangat tinggi. Guru yang terlihat keren, mudah bergaul dengan siswa, serta menyenangkan dalam mengajar bisa menjadi sebuah motivasi untuk siswa untuk lebih rajin.

Motivasi belajar terbagi menjadi dua, yaitu motivasi intrinsik dan ekstrinsik. Motivasi intriksik berasal dari dalam diri siswa itu sendiri sedangkan motivasi ekstrinsik berasal dari luar diri siswa. Motivasi dikarenakan perilaku terhadap pengajar atau guru termasuk ke dalam motivasi ekstrinsik. Seorang pengajar harus memiliki kemampuan menumbuhkan dan mengembangkan kedua jenis motivasi tersebut dengan kreativitas guru agar dapat menciptakan kondisi pembelajaran yang mengarahkan siswa untuk belajar dengan baik ${ }^{9}$. Kreativitas guru juga di tuntut disini untuk lebih mengupgrade dalam kegiatan pembelajaran di kelas . sehingga kreativitas gurupun akan teruji dalam menarik perhatian siswa agar semangat dan antusias dalam belajarnya. Guru yang kreatif adalah motivator siswanya.

Berdasarkan Tabel 2 dan Tabel 3 diketahui bahwa motivasi belajar integratif siswa kelas IPS lebih tinggi dari siswa kelas IPA. Begitu pula dengan motivasi instrumental, motivasi siswa kelas IPS lebih tinggi dari pada kelas IPA. Baik motivasi integratif maupun motivasi instrumental ini sama pentingnya dalam memicu keinginan siswa untuk belajar bahasa Inggris.

\section{SIMPULAN DAN SARAN}

Berdasarkan hasil penelitian mengenai perbandingan motivasi belajar Bahasa Inggris antara siswa kelas X-IPA dan kelas X-IPS, maka peneliti menarik kesimpulan yaitu persentase siswa kelas X-IPA dalam motivasi belajar integratif lebih rendah dari pada siswa kelas X IPS di SMAN 5 Banjarmasin. Hal ini terlihat pada poin komunikasi dengan orang luar dan status sosial( berpendidikan dan gengsi) hanya tinggi saja. Sedangkan persentase motivasi belajar integratif pada dua poin tersebut pada kelas X-IPS sangat tinggi. Adapun persentase siswa kelas X-IPA dalam motivasi belajar instrumental lebih rendah dari pada siswa kelas X IPS di SMAN 5 Banjarmasin. Hal ini terlihat pada persentase pada poin Keterkaitan dengan jurusan yang dipilih rendah serta persentase pada poin untuk keterkaitan sumber pelajaran sangat rendah daripada kelas X IPS. Peneliti juga menyimpulkan bahwa motivasi belajar itu sendiri ada yang berasal dari dalam diri siswa itu sendiri dan ada faktor luar sebagai pendukung yaitu guru sebagai motivator. Dimana seorang pengajar memang memiliki kewajiban untuk sekreatif mungkin menumbuhkan minat serta motivasi belajar pada perserta didik. Oleh karena itu, motivasi belajar antar siswa ini perlu di

${ }^{9}$ Ifni Oktiani, Kreativitas guru dalam meningkatkan Motivasi belajar Peserta didik.Jurnal kependidikan 5, -ejournal.uinsaizu.ac.id, 2017.

Al Qalam: Jurnal Ilmiah Keagamaan dan Kemasyarakatan Vol. 16, No. 1

Januari - Juni 2022 
Yulianti Hidayah, Fathul Zannah, Nana Citrawati Lestari : Perbandingan Motivasi Belajar Bahasa Inggris Antara Siswa Kelas X-IPA dan Kelas X-IPS

perhatikan oleh semua pihak yang terlibat dalam proses pembelajaran untuk upaya menghapus labelling ataupun diskriminasi yang selalu terpatri pada anak kelas IPA dan IPS. Dengan motivasi belajar,di harapkan anak IPA dan IPS akan lebih terarah dalam mencapai karir dan cita cita .Dalam penelitian ini, peneliti sangat sadar akan keterbatasan dalam penelitian yang di lakukan. Keterbatasan tersebut tentu saja berkaitan dengan proses penelitian yang di lakukan ini, salah satunya masih minimnya teori yang digunakan, serta metode yang di aplikasikan dalam penelitian ini.

\section{DAFTAR PUSTAKA}

Santosa, R.B. 2017. Motivasi dalam Pembelajaran Bahasa Inggris: Studi Kasus pada Mahasiswa Jurusan Pendidikan Bahasa Inggris IAIN Surakarta. Jurnal Ilmiah DIDAKTIKA Volume $18 \quad$ Nomor 11017. https://www.researchgate.net/publication/325042863_Motivasi_Dalam_Pembelajaran_B ahasa_Inggris Studi_Kasus Pada Mahasiswa Jurusan Pendidikan Bahasa_Inggris IA IN_Surakarta. Diakses 29 November 2020.

Taufiqurrochman, Ilham. 2018. Faktor-Faktor Yang Mempengaruhi Motivasi Belajar Bahasa Inggris. Skripsi. Surakarta: Universitas Muhammadiyah Surakarta.

D Warniati,Ul hanum. 2020. Sosialisasi pentingnya belajar Bahasa Inggris sejak dini di SD Inpres Workwana.distrik arso kabupaten Keerom.Jurnal AbdimasDinamis: Jurnal Pengabdian Masyarakat

Sauki maulana,Muh.2021.Pentingnya Bahasa Inggris untuk anak usia Dini di Kelurahan Mangasa. Jurnal lepa lepa Open:Jurnal Pengabdian Masyarakat.

Suryasa, Wayan I.2017. An analysis of student's motivation toward English Learning Among students in PEACE. International Journal of Social Sciences and Humanities.

Rahman SK,Abd,dkk. 2019.Labelling(studi komparatif pada siswa jurusan IPA dan IPS di MAN BINAMU JENEPONTO). Jurnal sosialisasi: jurnal hasil pemikiran, penelitian dan pengembangan keilmuan sosiologi pendidikan

Hanafi, Anrde Bagus.2018. Diskriminasi terhadap siswa IPS di SMA Surabaya(study Deskriptif tentang fenomena labelling yang di alami siswa IPS di SMAN 3 Surabaya dan SMA Barunawati Surabaya. Jurnal unair.ac.id

Arianti,A.2019. Peranan Guru dalam meningkatkan motivasi belajar siswa. Didaktika:Jurnal pendidikan 2019-mail.Jurnal.iain-bobe.ac.id

Bastari, E. 2019. Hubungan Motivasi Belajar peserta didik pada mata pelajaran IPS kelas IV SD Negeri 1 Sukabumi indah bandar lampung. Jurnal UIN Bandarlampung

Friantini, RN.2017. Pengaruh Motivasi Belajar terhadap Prestasi Belajar matematika siswa Kelas VIII SMPN Kuala Behe.Jurnal Ilmiah pendidikan :e-journal.unipma.ac.id

Cahyani,EP.2018. Hubungan antara Minat Belajar dan resiliensi matematis. E-journal.bbg.ac.id

Al Qalam: Jurnal Ilmiah Keagamaan dan Kemasyarakatan Vol. 16, No. 1

Januari - Juni 2022 
Yulianti Hidayah, Fathul Zannah, Nana Citrawati Lestari : Perbandingan Motivasi Belajar Bahasa Inggris Antara Siswa Kelas X-IPA dan Kelas X-IPS

Prayoga,RA,Khatimah,H.2019. Pola Pikir penggunaan Bhasa inggris pada masyarakat perkotaan di jabodetabek. Simulacra: Jurnal. Trunojoyo.ac.id

Yani, IA,Ratnamulyani,AA kusumadinata.2018. Pengaruh Kompetensi berbahasa asing dan pengorganisasian dalam menunjang karir di bidang Public relation.Jurnal KomunikatioUnida.ac.id

Septiani,NT.2019. Pengaruh ketekunan belajar dan kondisi sosialEknomi Keluarga terhadap hasil belajar IPS Siswa Kelas V SD Se-gugus martapuro Kecamatan tegal timur kota tegal. Semarang: Jurnal lib.unnes.ac.id , Universitas Negeri Semarang

Oktiani,Ifni.2017. Kreativitas guru dalam meningkatkan Motivasi belajar Peserta didik.Jurnal kependidikan 5, -ejournal.uinsaizu.ac.id

Al Qalam: Jurnal Ilmiah Keagamaan dan Kemasyarakatan Vol. 16, No. 1 Januari - Juni 2022 